\title{
NEOPLURAMYCIN, AN INHIBITOR OF NUCLEIC ACID SYNTHESIS
}

\author{
Isao Tsukada, Masa Hamada and Hamao Umezawa
}

Institute of Microbial Chemistry, Shinagawa-ku, Tokyo, Japan

Makoto Hori and Hidemi Hayashi

Showa College of Pharmaceutical Sciences, Setagaya-ku, Tokyo, Japan

(Received for publication December 16, 1970)

\begin{abstract}
A new antitumor antibiotic neopluramycin (NPM) exerts its effect on YosHiDA rat sarcoma cells primarily by inhibiting cellular nucleic acid synthesis. The mechanism of action of NPM was studied in various in vitro systems. It is suggested that at low concentrations, NPM intercalates into DNA double strands, resulting in a decrease in S-value of DNA and a metachromatic change of UV spectra of NPM-DNA solutions. Besides these effects, interaction of NPM with single-stranded polynucleotide chains is suggested by shifts of the UV absorption profiles of NPM in the presence of RNA or denatured DNA. At high concentrations, NPM causes an increase in the S-value of native DNA, the elevation of $\mathrm{Tm}$ of DNA and the acceleration of renaturation of heatdenatured DNA. From these observations, we presume that NPM at high concentrations makes the double-stranded structure of DNA somewhat tighter. We find that dinucleotides are the minimum-required structure for interaction with NPM, suggesting that the two neighbouring bases which are adjacent on a polynucleotide chain would sandwich a NPM molecule. Dinucleotides containing guanylyl residues did not show this effect; therefore, there must be some base specificity for the interaction.
\end{abstract}

A new antitumor antibiotic neopluramycin $(\mathrm{NPM})^{1)}, \mathrm{C}_{40} \mathrm{H}_{50} \mathrm{~N}_{2} \mathrm{O}_{10}$, was isolated from the culture filtrate of Streptomyces pluriocolorescens, and a quinoidal structure was suggested from its positive magnesium acetate reaction. NPM closely resembles pluramycin $\mathrm{A}(\mathrm{PM})^{2,3)}$ in biological activity except that NPM has much weaker effects against microorganisms than PM. We report in the present paper that NPM exerts its biological effects by modifying the structures and functions of nucleic acids, especially those of double stranded DNA. This conclusion was reached by studying the physicochemical effects of NPM on DNA in various in vitro systems.

\section{Materials and Methods}

RNA polymerase used in this study was an ammonium sulfate fraction from $E$. coli NIHJ prepared by the method of ChAMBERLin and BERG ${ }^{4}$. Tm of DNA was determined in a Gilford 2,400 spectrophotometer by the method of MANDEL and Marmur ${ }^{5)}$ with a modification that $0.1 \times \mathrm{SSC}(0.015 \mathrm{M} \mathrm{NaCl}+0.0015 \mathrm{M} \mathrm{Na}$ citrate) was used instead of $1.0 \times$ $\mathrm{SSC}$. The temperature in the cuvette chamber was raised rapidly to $50^{\circ} \mathrm{C}$ and from this point on it was raised at a rate of $4.5^{\circ} \mathrm{C}$ per hour using a Hak-PG-11 temperature controller. Renaturation of DNA was determined by the method of MARMUR ${ }^{6}$. E. coli DNA was isolated by the method of $\mathrm{MARMUR}^{7)}$. ${ }^{3} \mathrm{H}-\lambda c$ phage DNA and supercoiled DNA of SV- 
40 were kind gifts of Drs. M. Obinata and K. Oda, University of Tokyo, respectively. NPM and PM were supplied by Dr. S. Kondo of this institute. The following materials were obtained from commercial sources: EAGLE Medium from Daigo-Eiyo Co.; ATP, GTP, CTP, UTP from Boeringer Mannheim; calf thymus DNA from Worthington-Biochemical; ${ }^{14} \mathrm{C}$-leucine, ${ }^{3} \mathrm{H}$-uridine, ${ }^{3} \mathrm{H}$-thymidine from Dai-ichi Chemical Co.; ${ }^{3} \mathrm{H}$-UTP from New England Nuclear Chicago; and yeast RNA from Wako Pure Chemical Co.

\section{Results}

Effect of NPM on the Synthesis of DNA, RNA and Protein in Yoshida Sarcoma Cells

Yoshida sarcoma cells, cultured in vitro, were labeled with ${ }^{14} \mathrm{C}$-leucine, ${ }^{3} \mathrm{H}$-thymidine or ${ }^{3} \mathrm{H}$-uridine in the presence or absence of NPM. As shown in Fig. 1, NPM strongly inhibited both DNA and RNA syntheses at a concentration of $1 \mathrm{mcg} / \mathrm{ml}$ and the inhibition appeared immediately after the exposure of cells to NPM. Protein synthesis was reduced only slightly under the same condition. These results suggested, as one of several possibilities, that NPM interfered with the function of DNA tem. plates on which new DNA or RNA molecules are synthesized. Since this biochemical effect was observed at a concentration of $1 \mathrm{mcg}$ of NPM per $\mathrm{ml}$ (the concentration where cytotoxicity to the tumor cells was manifested), the mode of action of NPM is likely to be some interference with the structure and function of DNA. The following experiments were carried out to prove this assumption.

Fig. 1. Effect of NPM on the synthesis of cellular macromolecules.

YoshiDA sarcoma cells were grown in $0.5 \%$ of lactoalbumin medium at $37^{\circ} \mathrm{C}$ overnight (initial celldensity : $8 \times 10^{4}$ cells $/ \mathrm{m} 1$ ) and the cells were collected by centrifugation, washed with cold $1 / 15 \mathrm{M}$ phosphate buffer (PBS) of pH 7.2 and suspended in cold EAGLE's medium at a cell-density of $2 \times 10^{5} \mathrm{cells} / \mathrm{ml}$. Two ml aliquots of the cell suspension were taken in short test tubes and transferred in a water bath (37 $\mathrm{C}$ ). After 5-minute prewarming, $20 \mu 1$ of aqueous solution containing $1 \mu \mathrm{c}$ of ${ }^{3} \mathrm{H}$-thymidine, $1 \mu \mathrm{c}$ of ${ }^{3} \mathrm{H}$-uridine or $5 \mu \mathrm{c}$ of ${ }^{14} \mathrm{C}$-leucine was added. To the mixture, an appropriate amount of NPM dissolved in $20 \mu 1$ was added 2 minutes later (referred to as time 0). At indicated intervals, $0.05 \mathrm{~m} 1$ of the cell-suspension was removed and placed on Whatmann $3 \mathrm{MM}$ filter paper squares $\left(1 \times 1 \mathrm{~cm}^{2}\right)$ which were thereafter washed twice with cold $5 \%$ TCA, once with ethanol, and twice with ether. After drying, the paper squares were counted for radioactivity in a Beckman liquid scintillation counter with PPO-toluene system.

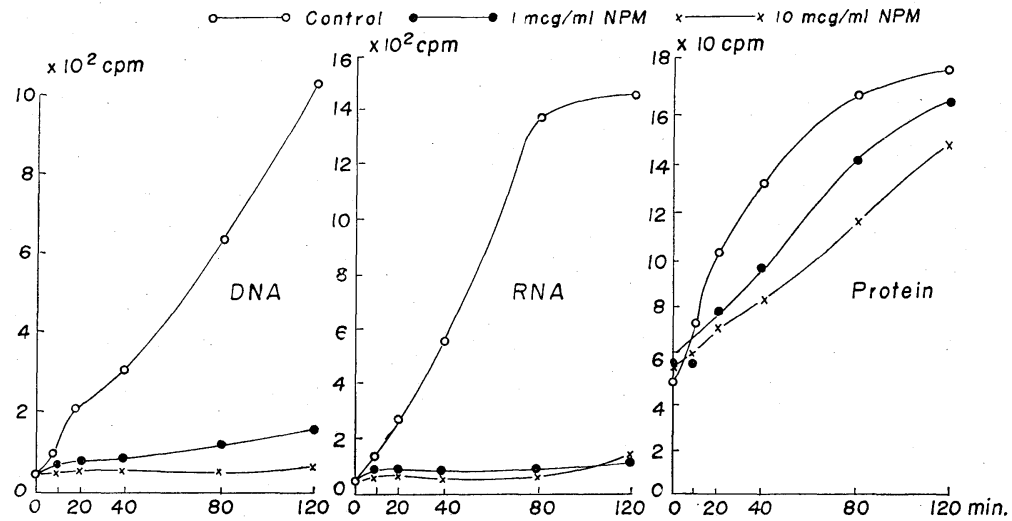

Inhibition of RNA Polymerase Reaction by NPM

Those compounds which interact with DNA could affect the RNA polymerase reaction in vitro ${ }^{8}$. This possibility was examined by testing DNA-dependent RNA synthesis in a system using calf thymus DNA as the template, an enzyme preparation 
from E. coli NIHJ and other components, as shown in Fig. 2. Approximately $50 \%$ inhibition of RNA synthesis was observed by NPM at a concentration of $2 \mathrm{mcg} / \mathrm{ml}$.

Elevation of the $\mathrm{Tm}$ of

\section{DNA by NPM}

Various antitumor drugs have been reported to change the $\mathrm{Tm}$ of DNA. Among them bleomycin ${ }^{9)}$ decreases the Tm, while actinomy$\operatorname{cin}^{10)}$, mitomycin ${ }^{11)}$ and phleomy$\operatorname{cin}^{12)}$ increase it. As shown in Fig. 3, NPM markedly elevated the Tm of calf thymus DNA. Since the optical density of the NPM-DNA solution was still increasing near the boiling point of the solution, the exact Tm of the NPM-DNA complex could not be determined. Moreover, the optical density of the NPM-DNA solution rose far beyond the upper level of the control. This suggests that NPM enters between base-

Fig. 3. Effect of PM and NPM on the Tm of DNA.

In a glass-capped cuvette of 1 -cm light path, $3 \mathrm{ml}$ of a test solution containing $60 \mathrm{mcg}$ calf thymus DNA, $0.015 \mathrm{M} \mathrm{NaCl}, 0.0015 \mathrm{M} \mathrm{Na}$ citrate and NPM or PM was placed. Optical density (O.D.) at $260 \mathrm{~m} \mu$ was read automatically in a Gilford spectrophotometer against the above solution which had no antibiotic. The thermal transition curves of test solutions were normalized by subtracting $\mathrm{O}$. $\mathrm{D}$. of the antibiotic read at $50^{\circ} \mathrm{C}$. The indicated values represent the ratio of the normalized O.D. at various temperature to the normalized O.D. at $50^{\circ} \mathrm{C}$.

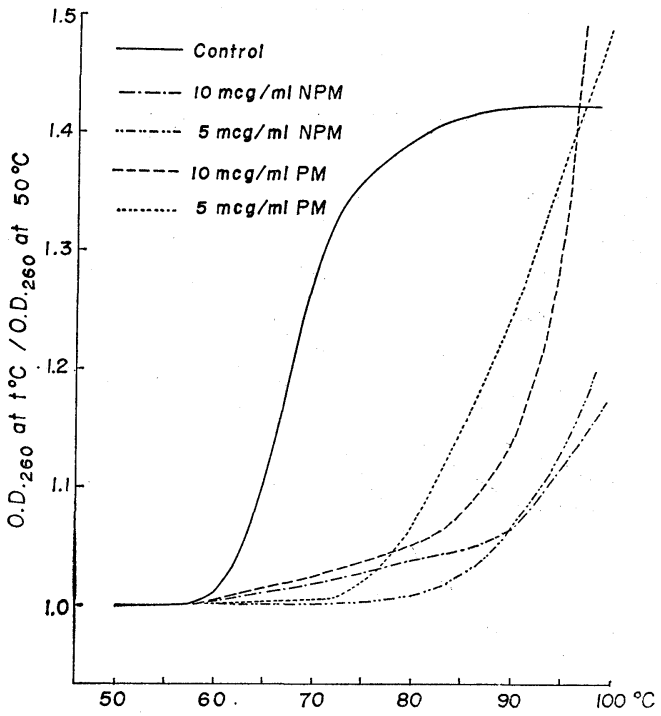

Fig. 2. Inhibition of RNA polymerase reaction by NPM.

A reaction mixture contained, in $0.25 \mathrm{ml}, 20 \mu$ mole of tris$\mathrm{HCl}$, final $\mathrm{pH} 7.9,3 \mu \mathrm{mole}$ of $\beta$-mercaptoethanol, $1 \mu$ mole of $\mathrm{MgCl}_{2}$, each $0.1 \mu \mathrm{mole}$ of ATP, GTP, CTP, $0.05 \mu$ mole of ${ }^{3} \mathrm{H}-$ $\mathrm{UTP}(20 \mu \mathrm{c} / \mu \mathrm{mole}), 0.25 \mu \mathrm{mole}$ of $\mathrm{MnCl}_{2}, 20 \mathrm{mcg}$ of calf thymus DNA, $20 \mu 1$ of enzyme (ammonium sulfate fraction) and various amounts of NPM. After preincubation for 2 minutes, the enzyme was added and the incubation was continued for 10 minutes at $37^{\circ} \mathrm{C}$. The reaction was stopped by adding $5 \mathrm{ml}$ of cold $5 \%$ TCA. Precipitates were collected by filtration and radioactivity determined in a Beckmann liquid scintillation counter with PPO-toluene system.

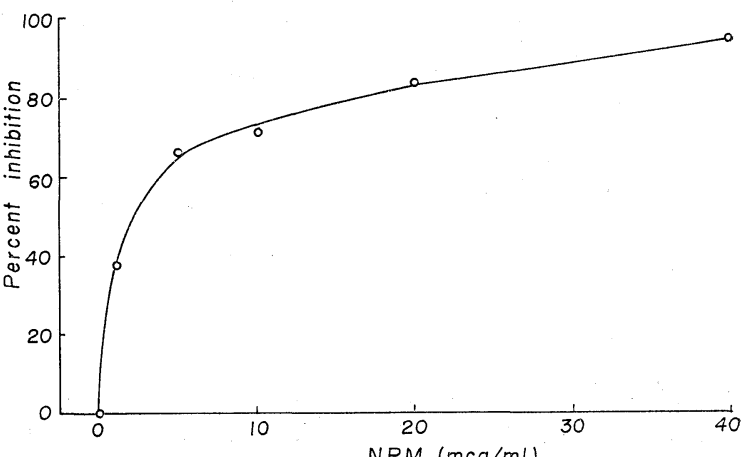

Fig. 4. Effect of NPM on the thermal transition of denatured $E$. coli DNA.

DNA isolated from $E$. coli NIHJ was dissolved at a concentration of $20 \mathrm{mcg} / \mathrm{ml}$ in a solution containing $0.3 \mathrm{M} \mathrm{NaCl}$ and $0.03 \mathrm{M}$ $\mathrm{Na}$ citrate. The solution was heated at $100^{\circ} \mathrm{C}$ for 10 minutes and chilled rapidly. An aliquot of this solution wes combined with an aliquot of the same buffer solution containing an appropriate amount of NPM and the mixture was placed in a capped quartzcuvette. The initial part (Melting) of the graph represents the increase in absorbance at $260 \mathrm{~m} \mu$ as the denatured DNA (with or without NPM) was heated up to $720^{\circ} \mathrm{C}$. The curves to the right of the vertical line (Renaturation) represent the decrease in absorbance of the renaturing samples as a function of time of exposure at $72^{\circ} \mathrm{C}$.

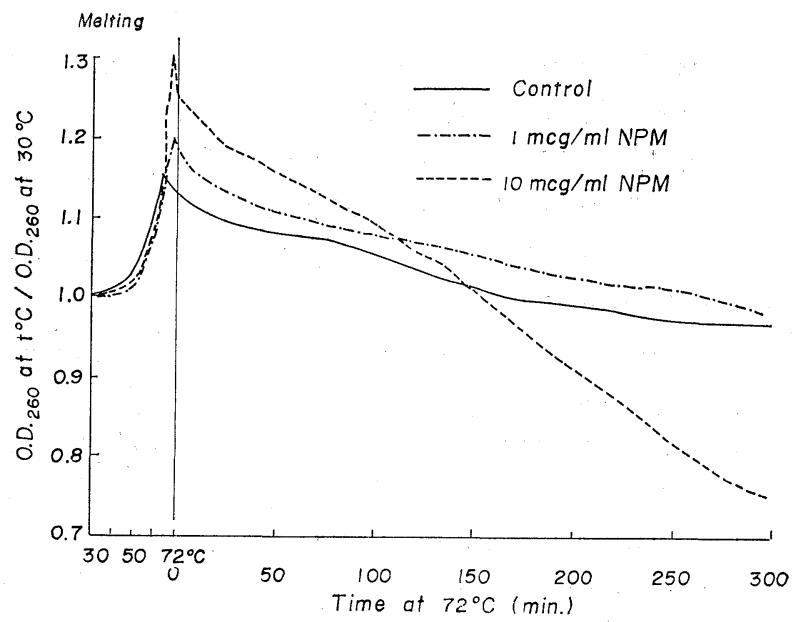


Fig. 5. Differential spectrum of NPM.

In a final volume of $3 \mathrm{ml}$ in a cuvette $(1 \mathrm{~cm}$ light pass), $0.45 \mathrm{ml}$ of $1 \times \mathrm{SSC}(0.15 \mathrm{M} \mathrm{NaC1}$ and $0.015 \mathrm{M} \mathrm{Na}$ citrate), $0.05 \mathrm{ml}$ of methanol solution of $1 \mathrm{mg}$ of NPM per $\mathrm{ml}$, and calf thymus DNA or yeast RNA were added. After incubation at $37^{\circ} \mathrm{C}$ for 30 minutes, the optical density of test solutions was read against the control which lacked NPM. Optical densities obtained at various wave lengths were subtracted from those of NPM alone, which had been read sparately in $1 \times \mathrm{SSC}$ and the values were plotted against the respective wave length to obtain the differential spectra.

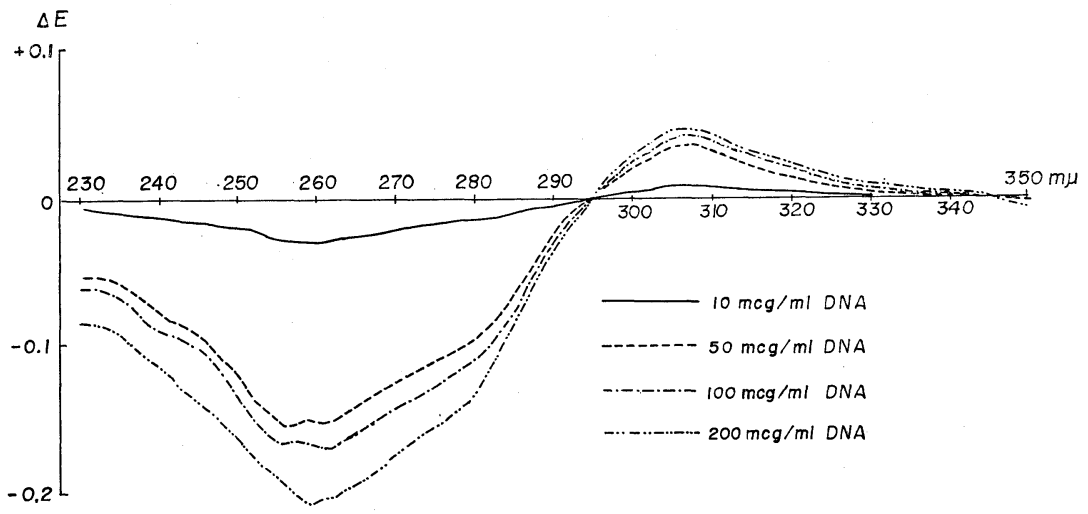

stacked pairs of DNA, and is then released when the double stranded structure of DNA is lost, resulting in the hyperchromicity.

Effect of NPM on the

Thermal Transition of Denatured DNA

It was demonstrated in the preceding experiment that the dissociation of double-stranded DNA into single strand DNA was reduced by NPM. We tested for the effect of NPM on the reverse process, that is, renaturation of denatured DNA. As shown in Fig. 4, NPM at a concentration of $10 \mathrm{mcg} / \mathrm{ml}$ accelerated the renaturation process. This result together with the preceding result suggests that NPM crosslinks the two strands of DNA and stabilizes the double-stranded structure. Covalent binding of NPM to DNA, which is known to be the case for nitrogen mustard

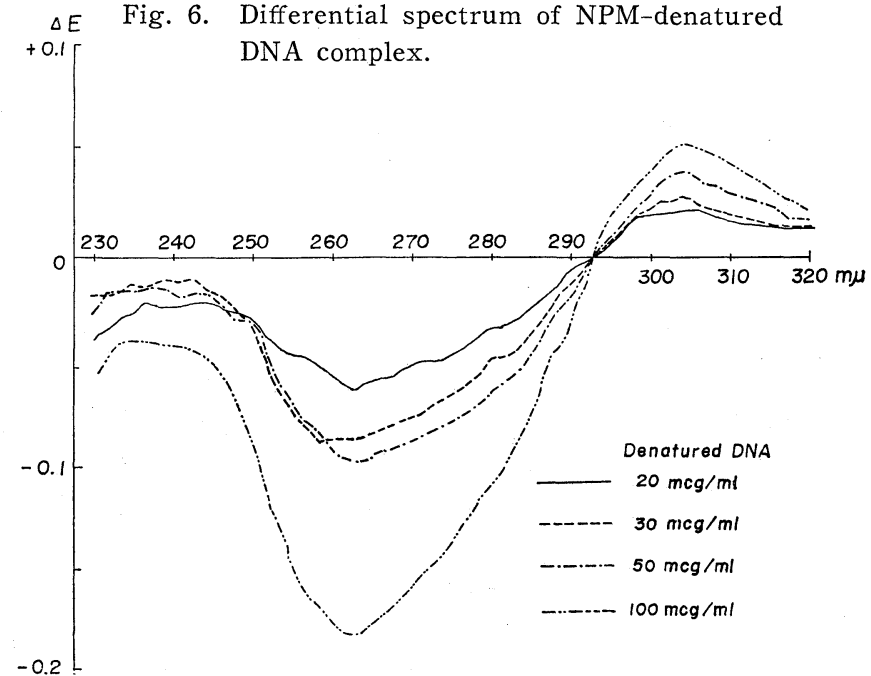

Fig. 7. Differential spectrum of NPM-RNA complex.

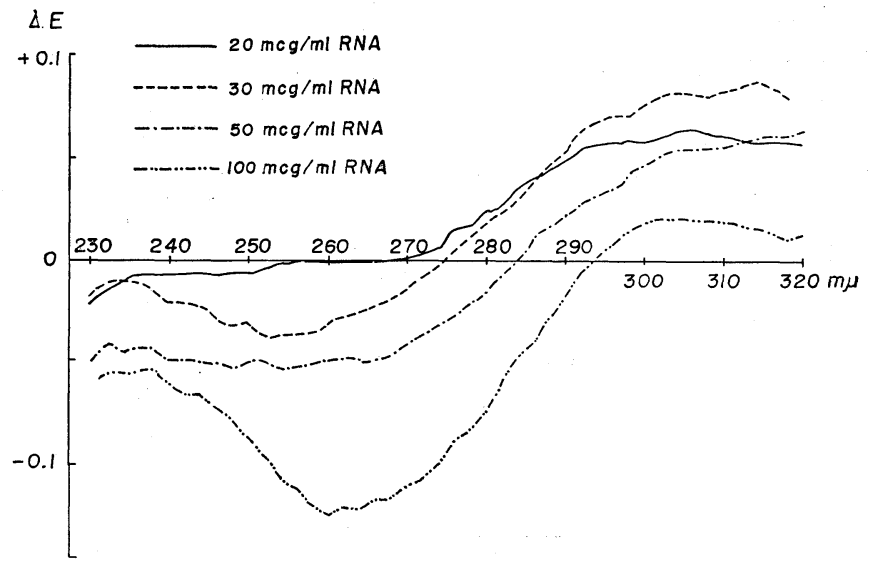


of reduced mitomycin $\mathrm{C}$, is not likely because NPM did not react with any deoxyribonucleoside $5^{\prime}$-phosphates.

Effect of DNA and RNA on the UV Absorption Spectra of NPM

Acridine orange and ethidium bromide ${ }^{13)}$, which have planar structures, are known to intercalate into DNA. When DNA was added to a solution of NPM, the UV absorption spectrum of NPM-DNA solution was found to be different from the simple sum of the spectra of NPM and DNA. The differential spectra of NPM with various amounts of DNA were obtained and plotted. As shown in Fig. 5, all the lines crossed at two isosbestic points at $295 \mathrm{~m} \mu$ and $345 \mathrm{~m} \mu$. As has been proposed in the case of ethidium bromide ${ }^{14)}$, the presence of the metachromatic effect suggests that NPM intercalates into DNA under these conditions and that the molecule of NPM, or at least a part of it, would be planar in structure. The effect of NPM on the renaturation of DNA indicates that NPM creates crosslinks between the two strands of DNA. It is probable that a part of a NPM molecule can sandwich between 2 neighbouring bases of a DNA strand and that another part of the NPM molecule could function in joining the complementary DNA strands. If this is the case, NPM should interact also with single-stranded DNA and RNA. In support of this proposal, NPM was found to change the UV absorption spectra of both heat-denatured DNA and RNA as shown in Figs. 6 and 7. In these cases, however, no metachromatic shift was observed. By contrast, the UV spectrum of nucleoside 5 -phosphates was not changed by NPM (data are not given).

Effect of NPM on the Sedimentation

Property of SV-40 DNA

The component I of SV-40 DNA is a closed circular, double-stranded and supercoiled molecule. As reported in the case of ethidium bromide ${ }^{15)}$, exposure of such a supercoiled form of DNA to increasing amounts of an intercalating drug sharply reduces the sedimentation velocity of DNA until it is equal to that of the slow component of DNA, form II. Further addition of the intercalating drug causes the reappearance of supercoiled form. This is interpreted as being due to the loss and then to the reversal of the supercoiling turns in the DNA molecule by intercalation. As shown in Fig. 8, over a concentration range of 1 to $10 \mathrm{mcg}$ of $\mathrm{NPM}$ per $\mathrm{ml}$, the sedimentation velocity of the supercoiled DNA in the sucrose density gradient was

Fig. 8. Effect of NPM on the sedimentation pattern of SV 40 DNA.

0.3 O. D. units of supercoiled DNA from SV-40 (component I) and NPM were dissolved in $0.2 \mathrm{ml}$ of water and the solution was layered on to $5 \sim$ $20 \%$ sucrose gradient containing $0.02 \mathrm{M}$ Tris- $\mathrm{HCl}$ $\mathrm{pH} 8.5,0.1 \mathrm{M} \mathrm{NaCl}, 0.001 \mathrm{M}$ EDTA, and NPM whose concentration in the gradient was adjusted to the same as that of the solution applied. Centrifugation was for 4.5 hours at 40,000 r.p.m. in a RPS 40 rotor $(130,000 \times g)$ in a Hitachi 65 P Ultracentrifuge. After centrifugation, optical density was continuousiy read by an Otake UV recorder.
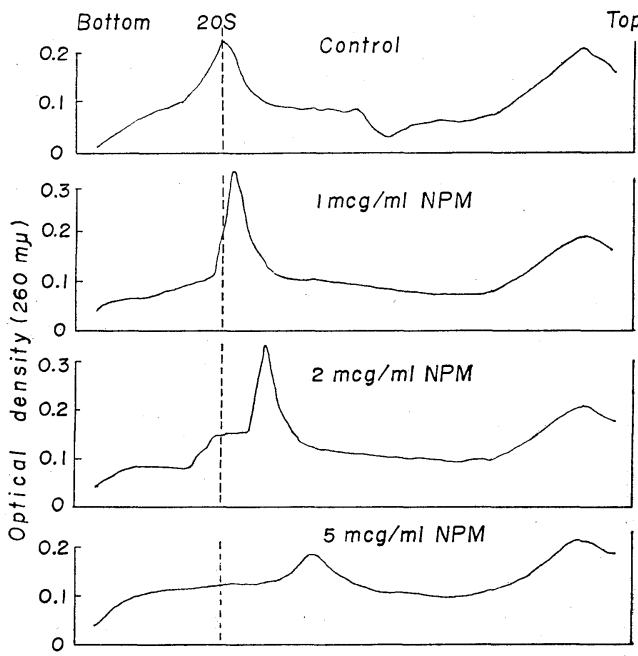

$10 \mathrm{mcg} \mathrm{ml} / \mathrm{NPM}$

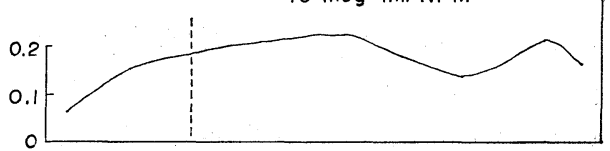


reduced markedly and this is consistent with an intercalation model. However, it should be noticed in the sedimentation profiles that the peak became sharp in the presence of 1 2 mcg of NPM per $\mathrm{ml}$, while it was flattened in the presence of $5 \sim 10$ mcg of NPM per ml. These results suggest that NPM is not a simple intercalating agent but that it has some complex effect on the DNA structure.

Effect of NPM on the

Sedimentation Property of $\lambda c$ Phage DNA

The DNA of $\lambda c$ phage has a linear, double-stranded structure. As shown in Fig. 9 , in the presence of $2 \mathrm{mcg}$ of NPM per ml, DNA sedimented in the sucrose gradient somewhat more slowly than in the absence of the
Fig. 9. Effect of NPM on the sedimentation pattern of ${ }^{3} \mathrm{H}-\lambda c$ DNA.

Two $\mu \mathrm{g}$ of ${ }^{3} \mathrm{H}-\lambda c$ phage DNA and appropriate amount of NPM was dissolved in $0.2 \mathrm{ml}$ of water and layered on the gradient. Other procedures were identical with those stated under the legend to Fig. 8 except that the gradients were centrifuged for 2.5 hours.

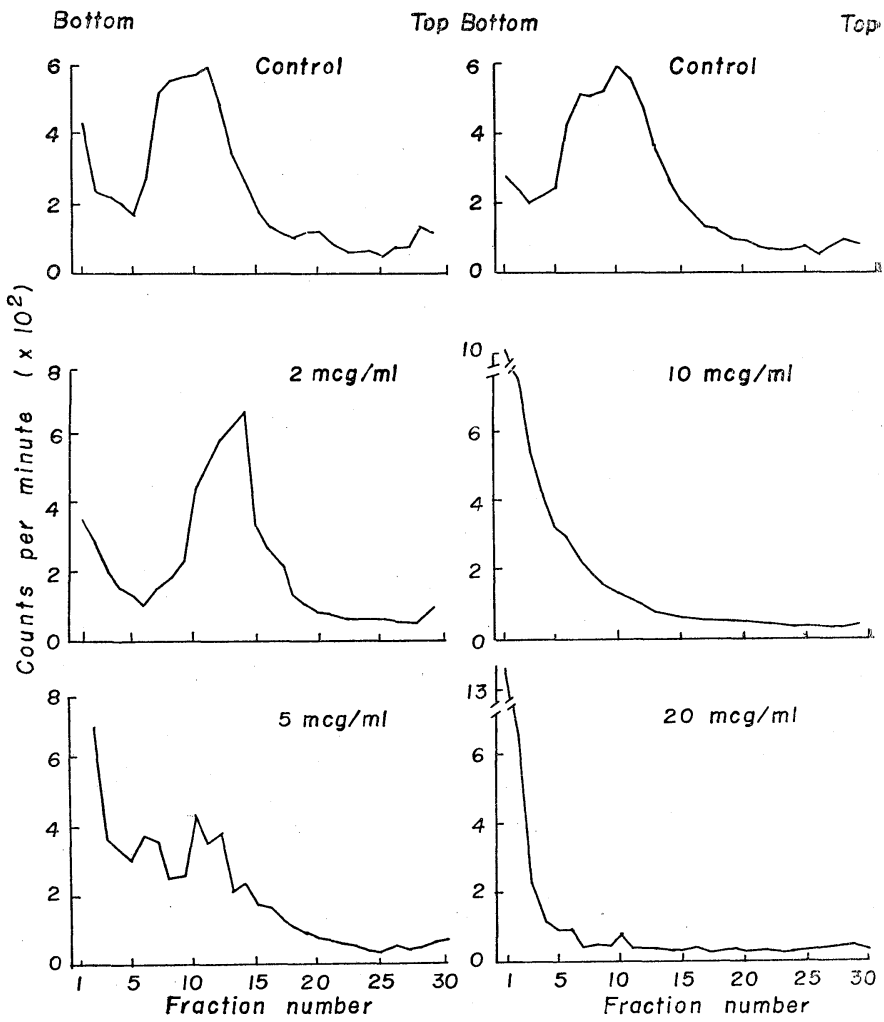
drug; this is consistent with an intercalation model. However, in the presence of 10 20 mcg of NPM per ml, DNA sedimented to the bottom of the centrifuge tube. Sedimentation profiles of NPM-treated DNA in an alkaline sucrose density gradient were almost identical with that of control, as shown in Fig. 10.

\section{Interaction of NPM with Deoxyribodinucleotides}

Evidence has been presented so far that NPM interacts with native DNA, denatured DNA, and with RNA. The antibiotic failed to show, however, any interaction with either single, or with a combination of deoxyribomononucleotides (data are not shown). If polynucleotides (DNA or RNA) interact with NPM by a mechanism which involves sandwiching the NPM molecule between two neighbouring bases, then the minimum-required structure for polynucleotides to interact with NPM would be a dinucleotide or a dinucleoside monophosphate. To confirm this assumption, the following experiments were conducted. Two deoxyribonucleotide fractions, one containing a deoxyriboguanylyl residue and the other not, were prepared from a DNase digest of calf thymus DNA by the method of TomLinson and TENER ${ }^{16)}$. Chromatographic analysis of the latter fraction revealed the presence of some contaminating mononucleotides. Differential spectra of these nucleotide solutions in the presence of 
Fig. 10. Effect of NPM on the sedimentation pattern of ${ }^{3} \mathrm{H}-\lambda c$ phage DNA at $\mathrm{pH} 12$.

The procedures were identical with those stated under the legend to Fig. 9 except that the sucrose gradients were adjusted to $\mathrm{pH} 12$ with $\mathrm{NaOH}$ and centrifuged for 1.5 hours.

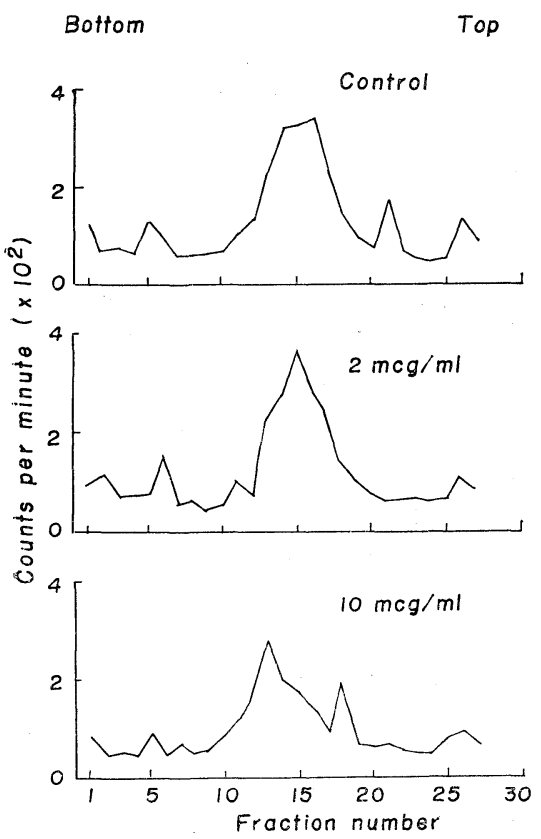

Fig. 11. Differential spectrum of NPM-dinucleotide complex. The procedures were identical with those stated under the legend to Figs. 5, 6, 7 except that the nucleic acids were replaced by dinucleotide.

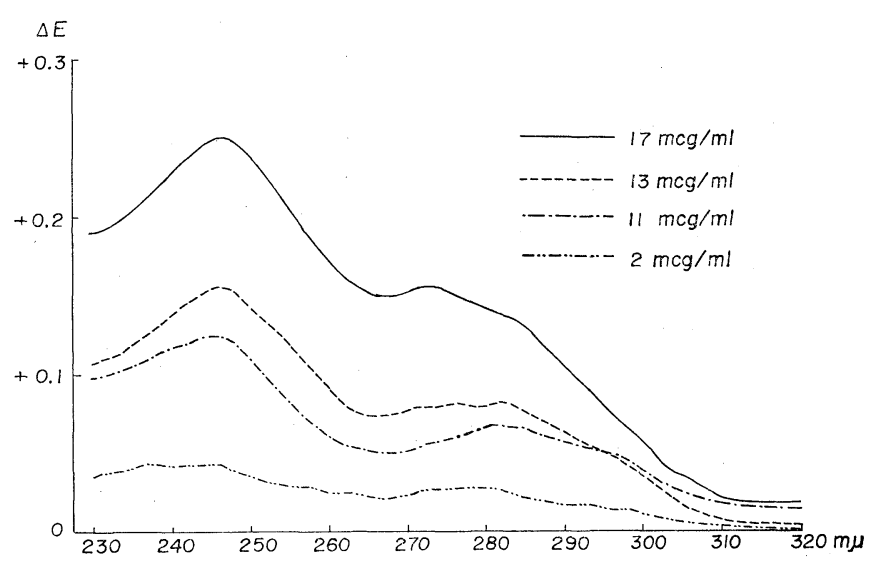

various amounts of NPM were obtained. As shown in Fig. 11, only those deoxyribodinucleotides which did not include a deoxyguanylyl residue interacted well with NPM. These observations indicate that a deoxyribodinucleotide would be the minimum structure for interaction with NPM, and in addition that there must be some specificity in the base sequence. It should be noticed that the dinucleotide-NPM complexes showed positive differential spectra, as shown in this figure, in contrast to negative differential spectra of DNA-NPM or RNA-NPM complexes which were shown earlier (Figs. 5, 6, 7). It is not known if there is any basic difference between the formation of a dinucleotide-NPM complex and that of a polynucleotide-NPM complex. The latter must involve the changes of secondary or tertiary structure of DNA.

\section{Discussion}

Evidence is presented which supports the notion that NPM intercalates into doublestranded DNA and it is presumed that a planar portion of the NPM molecule forms a sandwich-like structure between two neighbouring bases of double stranded DNA. Though the structure of NPM has not been determined, its quinoid nature suggests the existence of a planar part in the molecule. The intercalation effect is clearly observed at low concentrations of NPM. Another part of the NPM molecule is thought to cross-link the double-stranded structure of DNA since high concentrations of NPM increased the Tm of DNA, decreased the S-value of DNA and accelerated the rate of renaturation of heatdenatured DNA. A co-valent bond formation between NPM and DNA is unlikely because they form a complex simply by mixing under mild conditions, and because the complex thus formed can be dissociated on heating. The effects of pluramycin ${ }^{17,18)}$, as described by TANAKA et al. are similar to those described for NPM at high concentrations.

\section{References}

1) Kondo, S.; T. Wakashiro, M. Hamada, K. Maeda, T. Takeuchi \& H. Umezawa: Isolation and characterization of a new antibiotic, neopluramycin. J. Antibiotics $23: 354 \sim 359,1970$ 
2) Takeuchi, T.; K. Nitta \& H. Umezawa : Antitumor effect of pluramycin crude powder on Ehrlich carcinoma of mice. J. Antibiotics, Ser. A $9: 22 \sim 30,1956$

3) Maeda, K.; T. Takeuchi, K. Nitta, K. Yagishita, R. Utahara, T. Osato, M. Ueda, S. Kondo, Y. Oкамi \& H. Umezawa: A new antitumor substance, pluramycin. J. Antibiotics, Ser. A $9: 75 \sim 81,1956$

4) Chamberlin, M. \& P. Berg: Deoxyribonucleic acid directed synthesis of ribonucleic acid by enzyme from Escherichia coli. Proc. Nat. Acad. Sci. 48 : 81 94, 1962

5) Mandel, M. \& J. Marmur : Use of ultraviolet absorbance-temperature profile for determiningthe guanine plus cytosine content of DNA. Methods in Enzymology 12B : 195 206, 1968

6) Marmur, J. \& P. Doty : Thermal renaturation of deoxyribonucleic acids. J. Mol. Biol. $3: 585$ $\sim 594,1961$

7) Marmur, J. : A procedure for the isolation of deoxyribonucleic acid from micro-organisms. J. Mol. Biol. $3: 208 \sim 218,1961$

8) Kageyama, M.; M. Hasegawa, A. Inagaki \& F. Egami : Interaction of antibiotics with deoxyribonucleic acid. J. Biochem. $67: 549 \sim 557,1970$

9) Nagai, K.; H. Yamaki, H. Suzuki, N. Tanaka \& H. Umezawa: The combined effects of the bleomycin and sulfydryl compound on the thermal denatutration of DNA. Biochem. Biophys. Acta $179: 165 \sim 171,1969$

10) Reich, E. \& I. H. Goldberg: Actinomycin and nucleic acid function. In Progress in Nucleic Acid Research and Molecular Biology $13: 184 \sim 234,1964$

11) Szybalski, W. \& V. N. Iyer : Cross-linking of DNA by enzymatically or chemically activated mitomycins and profiromycins, bifunctionally "alkylating" antibiotics. Fedn. Proc. (Fedn. Amer. Soc. Exp. Biol.) 23 : 946 956, 1964

12) Falaschi, A. \& A. Kornberg: Phleomycin, an inhibitor of DNA polymerase. Fedn. Proc. (Fedn. Amer. Soc. Exp. Biol.) $23: 940 \sim 945,1964$

13) WARING, M. J. : Drug which affect the structure and function of DNA. Nature 219:1320 1325, 1968

14) Waring, M. J. : Complex formation between ethidium bromide and nucleic acids. J. Mol. Biol. $13: 269 \sim 282,1965$

15) CRAWford, L. V. \& M. J. WARING : Supercoiling of polyoma virus DNA measured by its interaction with ethidium bromide. J. Mol. Biol. $25: 23 \sim 30,1967$

16) Tombinson, R. V. \& G. M. Tener : The effect of urea, formamide, and glycols on the secondary binding forces in the ion-exchange chromatography of polynucleotides on DEAE-cellulose. Biochemistry $2: 697 \sim 702,1963$

17) NagaI, K.; N. TanaKa \& H. UmezaWA: Inhibition of nucleic acid biosynthesis in cell-free synthesis of Escherichia coli B by pluramycin. J. Biochem. $67: 655 \sim 660,1970$

18) Tanaka, N.; K. Nagai, H. Yamaguchi \& H. Umezawa : Inhibition of RNA and DNA polymerase reactions by pluramycin. Biochem. Biophys. Res. Commun. $21: 328 \sim 332,1965$ 